\title{
NUTRITIONAL STATUS OF SCHOOL-GOING ADOLESCENTS IN EASTERN PART OF NEPAL
}

\author{
Kafle $T K^{1^{*}}$, Kafle $T K^{2}$, Hawlader $D H^{3}$, Rimal $H S^{4}$, Sapkota $D^{5}$
}

\begin{abstract}
Affiliation
1. Lecturer, Department of Community Medicine, Birat Medical College and Teaching Hospital, Nepal.

2. Assistant Proffessor, Department of Community Medicine, Birat Medical College and Teaching Hospital, Nepal.

3. Associate Professor, Department of Epidemiology North-South University, Dhaka, Bangladesh, Nepal

4. Professor, Department of Paediatrics, Birat Medical College Teaching Hospital.

5. Research Officer, Millstone Institute of Health Research and Development Nepal Research Officer.
\end{abstract}

\section{ARTICLE INFO}

Received : 12 December, 2019
Accepted : 18 February, 2020
Published : 30 June, 2020

(C) Authors retain copyright and grant the journal right of first publication with the work simultaneously licensed under Creative Commons Attribution License CC - BY 4.0 that allows others to share the work with an acknowledgment of the work's authorship and initial publication in this journal.

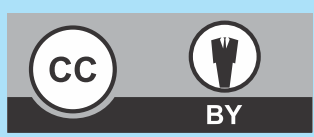

ORA 159

DOI: https://doi.org/10.3126/bjhs.v5i1.29628

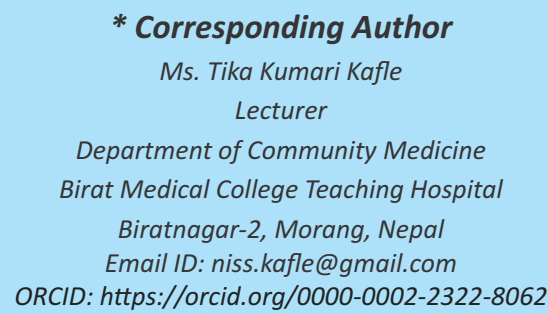

\section{Citation}

Kafle TK, Kafle TK, Hawlader DH, Rimal HS, Sapkota D. Nutritional Status of School-Going Adolescents in Eastern Part of Nepal. BJHS 2020;5(1)11: 932-937.

\section{ABSTRACT}

\section{Introduction}

Nutrition is one of the key factors that affects every sphere of human health. Its effect on physical and cognitive development is vital for performance and productivity especially among the children and adolescents. Hemoglobin and body mass index (BMI) are key factors to assess the nutritional status among adolescents.

\section{Objectives}

This study aims to examine the nutritional status and its associated factors among school-going adolescents

\section{Methodology}

Descriptive cross-sectional study design was adopted with sample size 810 involving 11 to 17 years' school going adolescents in Eastern Development Region of Nepal. Multistage probability sampling technique was used to draw the sample and pre-designed structured questionnaire and standard measurement tools were used to assess the nutritional status. Ethical approval and written informed consent were taken from concerned authorities. Data were entered in EPI Data and analyzed by SPSS. Chi-square test was used to find association.

\section{Results}

Among 810 adolescents, $52.5 \%$ were females and $47.5 \%$ were males. The mean age of participants was 14.5 years. Mean hemoglobin and BMI were measured $11.13 \mathrm{mg} / \mathrm{dl}$ with SD 1.57 and 18.87 with SD 2.79 respectively. Variation measured significant by sex, ethnicity, parents' education, family type and ecological belts for BMI $(p<.05)$. Similarly, age, sex, ethnicity, property index, parents' education and occupation were significantly associated with hemoglobin $(p<.05)$.

\section{Conclusion}

The low BMI as well asanemia were widely prevalent among school-going adolescents in Eastern part of Nepal. The females had better BMI than males but males were less anemic than females.

\section{KEY WORDS}

Adolescents, body mass index, hemoglobin, nutrition 


\section{INTRODUCTION}

Good nutrition is prerequisite for optimal health; fundamental to child growth and development as well as in the prevention and recovery of any disease. ${ }^{1}$ Nutrition is one of the key factors that affects every sphere of human life and determines the quality of life. It is also an important health indicator to assess the health status and morbidity pattern of any specified area and population. ${ }^{2-4}$ Nutritional intake affects health and cognitive development; is vital for both academic performance and productivity., Malnutrition contributes to an estimated 200 million children failing to attain their full development potential'. Many children and adolescents become stunted, wasted and under weight due to severe under nutrition, leading to hampered cognitive and physical development. ${ }^{8,9}$ These conditions also lead to increased risk of morbidity and mortality particularly from infectious disease such as diarrhea and pneumonia. Iron and lodine deficiencies along with stunting and under weight contribute children not achieving their full potential. At the same time, overweight and obesity in children and adults have been increasing rapidly in all region of the world. ${ }^{10}$

A cross-sectional study conducted by Singh $\mathrm{P}$ et.al revealed the prevalence of Iron deficiency anemia among children was $65.6 \%$ in Biratnagar city of Nepal, comprising $62.4 \%$ among rural and $70 \%$ among urban and $52.3 \%$ among males and $78.3 \%$ among females. ${ }^{11}$ Another community based study on school going adolescents in 2009 carried out by Baral KP and Onta SR revealed that the overall prevalence of anemia among adolescents was very high (65.6\%). Among female adolescents (78.3\%) the figure was still high; more than $25.0 \%$ higher than males (52.3\%). Difference between rural and urban anemia found striking.

Although malnutrition being a serious public health problem, in most of the developing countries including Nepal, there are rare studies on the prevalence and severity of malnutrition among adolescents in Nepal. ${ }^{12,13}$ Studies focusing on the nutritional status of adolescent girls comparing with adolescent boys are probably not available in the region. Therefore, this study aimed to dig out the magnitude, pattern and severity of malnutrition among adolescent girls and its comparison with boys in Eastern Development Region of Nepal.

\section{METHODOLOGY}

Descriptive cross-sectional study design was adopted in this study. The sample size in this study was 810 school going adolescents aged 11 to 17 years. Sample size was calculated by using following formulae considering $50 \%$ prevalence:

$\mathrm{n}=2 * \mathrm{Z}^{2} \mathrm{PQ} / \mathrm{d}^{2}$

$\mathrm{n}=2 *(1.96)^{2} * 50 * 50 /(5)^{2}=800$

Here, extra 10 samples were taken to address incompleteness so total sample size was 810 . The sample size was multiplied by 2 in order to reduce the design effect of the study.

Where, $\mathrm{P}=50 \%, \mathrm{Z}=1.96$ in $5 \%$ level of significance and $10 \%$ relative permissible error has been considered.

The study sample was obtained using multistage cluster sampling technique. In the first phase, five districts (Morang, Siraha Ilam, Udayapur, and Sangkhuwasabha) were selected by using probability sampling technique; one from mountain and two from each Hill and Terai to represent all ecological belts of Eastern Development Region. In second stage, three schools from each district were selected randomly from the list of total schools. Equal numbers of sample size were generated from each district; however, in two districts we got five more samples than required. Therefore, 40-45 participants were selected from each selected school by using simple random sampling technique. Questionnaire was developed by taking consultation with three subject and research experts. Ethical approval was obtained from ethical board of Nepal Health Research Council and written consent was taken from each participants and parents to participate in the study. Direct interview was done and standard weighting machine and measuring tape were used to measure the height and weight of the participants. Valid hemoglobinometer was used to measure the hemoglobin. Collected data were checked for its consistency. BMI and anemia category were made according to the WHO criteria for Asian countries. Data were entered in EPI data software then transferred to SPSS (version 16) for statistical analysis. Frequency tables and cross-tables were generated as per necessary and chisquare-test was applied to examine the effect of variables.

\section{RESULT}

The study measured Body Mass Index (BMI) and hemoglobin of the adolescents as the indicator of nutritional status. Among 810 adolescents, less than half (45.4\%) were found with normal BMI status and the rest were undernourished $(47.3 \%$ had low BMI and $7.3 \%$ were overweight and obese). Similarly, only about one-forth (26.5\%) adolescents had normal Hemoglobin level and the remaining $73.5 \%$ were measured anemic. About $30 \%$ had mild anemia, $41 \%$ moderate and $2.5 \%$ had severe anemia (Table 1).

Table 1: BMI and Hemoglobin Level of the Respondents
\begin{tabular}{|l|l|c|c|}
\hline Characteristics & \multicolumn{1}{|c|}{ Category } & Frequency & Percent \\
\hline BMI & Low (<18.5) & 383 & 47.3 \\
& Normal(18.5 -22.9) & 368 & 45.4 \\
& Overweight/Obese(>23) & 59 & 7.3 \\
& Mean BMI士SD & $18.87 \pm 2.79$ & \\
\hline \multirow{3}{*}{ Hemoglobin } & Normal (>12 or 11.5) & 215 & 26.5 \\
& MildAnemia (10-11.9/10-11.4)) & 239 & 29.5 \\
& ModerateAnemia (8-9.9) & 336 & 41.5 \\
& SevereAnemia (<8) & 20 & 2.5 \\
& Mean HB \pm SD & $11.13 \pm 1.57$ & \\
\hline Total & & $\mathbf{8 1 0}$ & 100 \\
\hline
\end{tabular}

Table 2 displays the status of BMI by age, sex and ethnicity. The BMI was found better among late adolescents in comparison to early adolescents. More than half $(52.4 \%)$ adolescents between the ages $15-17$ years were found with normal BMI and it was 38.1\% among age group $11-14$ years. Similarly, 55.8 percent early adolescents had low BMI and the same figure was $39.2 \%$ among late adolescents. The proportion of overweight and obesity was also higher among late adolescents (8.4\%) than early adolescents (6.1\%). 
Table 2: Distribution of Respondents' Body Mass Index (BMI) by Age, Sex and Ethnicity

\begin{tabular}{|c|c|c|c|c|}
\hline \multirow[b]{2}{*}{ Variables } & \multicolumn{3}{|c|}{ BMI } & \multirow[b]{2}{*}{$\begin{array}{l}\text { Chi-square } \\
\text { and P-value }\end{array}$} \\
\hline & $\begin{array}{l}\text { Low } \\
\mathrm{N}(\%)\end{array}$ & $\begin{array}{l}\text { Normal } \\
\mathbf{N}(\%)\end{array}$ & $\begin{array}{l}\text { Overweight/ } \\
\text { Obese N (\%) }\end{array}$ & \\
\hline $\begin{array}{l}\text { Age } \\
11 \text { to } 14 \text { years } \\
>14 \text { years }\end{array}$ & $\begin{array}{l}220(55.8) \\
163(39.2)\end{array}$ & $\begin{array}{l}150(38.1) \\
218(52.4)\end{array}$ & $\begin{array}{l}24(6.1) \\
35(8.4)\end{array}$ & $\begin{array}{c}x^{2}=22.52 \\
P<.01\end{array}$ \\
\hline $\begin{array}{l}\text { Sex } \\
\text { Male } \\
\text { Female } \\
\end{array}$ & $\begin{array}{l}210(54.5) \\
173(40.7)\end{array}$ & $\begin{array}{l}155(40.3) \\
213(50.1)\end{array}$ & $\begin{array}{l}20(5.2) \\
39(9.2)\end{array}$ & $\begin{array}{c}x^{2}=16.90 \\
P<.01\end{array}$ \\
\hline $\begin{array}{l}\text { Caste/Ethnicity } \\
\text { Hill Brahmin/Chhetri } \\
\text { Terai Brahmin/Chhetri } \\
\text { Adibasi/Janajati } \\
\text { Dalits } \\
\text { Others }\end{array}$ & $\begin{array}{c}124(52.8) \\
110(57.9) \\
114(37) \\
29(43.9) \\
6(54.5)\end{array}$ & $\begin{array}{c}100(42.6) \\
71(37.4) \\
162(52.6) \\
30(45.5) \\
5(45.5)\end{array}$ & $\begin{array}{c}11(4.7) \\
9(4.7) \\
32(10.4) \\
7(10.6) \\
0\end{array}$ & $\begin{array}{c}x^{2}=29.55 \\
P<.05\end{array}$ \\
\hline
\end{tabular}

Table 3 presents the status of BMI of adolescents according to their parent's education and occupation. There was no significant difference observed in BMI status of adolescents according their parents education ( $p>05$ ). However, higher proportion (53.2\%) of adolescents had normal BMI whose father had higher education. Similarly, higher percentage (51.4\%) of adolescents had normal BMI whose fathers' main occupation was service. However, the difference was not significant in BMI by parents' occupation ( $p>05$ ). Nearly three adolescents in every five (57\%) had normal BMI whose mothers were homemakers followed by mothers' service occupation (49\%).

\begin{tabular}{|c|c|c|c|c|}
\hline \multirow[b]{2}{*}{ Variables } & \multicolumn{3}{|c|}{ Body Mass Index(BMI) } & \multirow{2}{*}{\begin{tabular}{|c} 
Chi Square \\
$\&$ \\
P value \\
\end{tabular}} \\
\hline & Low BMI & Normal & $\begin{array}{c}\text { Overweight/ } \\
\text { Obese }\end{array}$ & \\
\hline \multicolumn{5}{|l|}{ Father's education } \\
\hline Not stated & $9(45)$ & $11(55)$ & 0 & $x^{2}=7.423$ \\
\hline No education & $52(52)$ & $43(43)$ & $5(5)$ & $\mathrm{P}=0.283$ \\
\hline Primary education & $83(50.9)$ & $68(41.7)$ & $12(7.4)$ & \\
\hline Secondary education & $178(48.2)$ & $162(43.9)$ & $29(7.9)$ & \\
\hline Higher education & $61(38.3)$ & $84(53.2)$ & $13(8.2)$ & \\
\hline \multicolumn{5}{|l|}{ Mother's education } \\
\hline Not stated & $8(44)$ & $10(55.6)$ & 0 & $x^{2}=7.058$ \\
\hline No education & $106(45.1)$ & $117(49.8)$ & $12(5.1)$ & $\mathrm{P}=0.315$ \\
\hline Primary education & $91(48.4)$ & $79(42)$ & $18(9.6)$ & \\
\hline Secondary education & $141(50.4)$ & $118(42.1)$ & $21(7.5)$ & \\
\hline Higher education & $37(41.6)$ & $44(49.4) \%$ & $8(9)$ & \\
\hline \multicolumn{5}{|l|}{ Father's Occupation } \\
\hline Not stated & $6(60)$ & $4(40)$ & 0 & $x^{2}=11.083$ \\
\hline Agriculture & $153(46.8)$ & $154(47.1)$ & $20(6.1)$ & P 0.522 \\
\hline Business & $101(47.6)$ & $90(42.5)$ & $21(9.9)$ & \\
\hline Service & $48(44)$ & $56(51.4)$ & $5(4.6)$ & \\
\hline Labour/Worker & $39(54.2)$ & $29(40.3)$ & $4(5.6)$ & \\
\hline Foreign employment & $33(44.6)$ & $32(43.2)$ & $9(12.2)$ & \\
\hline Others & $3(50)$ & $3(50)$ & 0 & \\
\hline \multicolumn{5}{|l|}{ Mother's Occupation } \\
\hline Not stated & $5(62.5)$ & $3(37.5)$ & 0 & $x^{2}=19.011 a$ \\
\hline Agriculture & $203(49.2)$ & $186(45)$ & $24(5.8)$ & $\mathrm{P}=0.088$ \\
\hline Business & $67(43.8)$ & $70(45.8)$ & $16(10.5)$ & \\
\hline Service & $23(46.9)$ & $24(49)$ & $2(4.1)$ & \\
\hline Labour/Worker & $11(45.8)$ & $11(45.8)$ & $2(8.3)$ & \\
\hline Foreign employment & $42(60)$ & $21(30)$ & $7(10)$ & \\
\hline Housewife & $32(34.4)$ & $53(57)$ & $8(8.6)$ & \\
\hline
\end{tabular}

While observing the Hemoglobin of adolescents by different socio-demographic characteristics, the sex, fathers' and mothers' education as well as property index were found positively

associated with normal Hemoglobin level. Adolescents with high property index had better Hemoglobin (33\% normal) as compared to medium ( $27.8 \%$ normal) and low $(19.8 \%$ normal) property index $(p<.01)$. Similarly, the males had better hemoglobin level than the females $(p<.05)$. Adolescents with educated father and mother had better hemoglobin level as compared to primary level or less education (Table 4 \& 5).

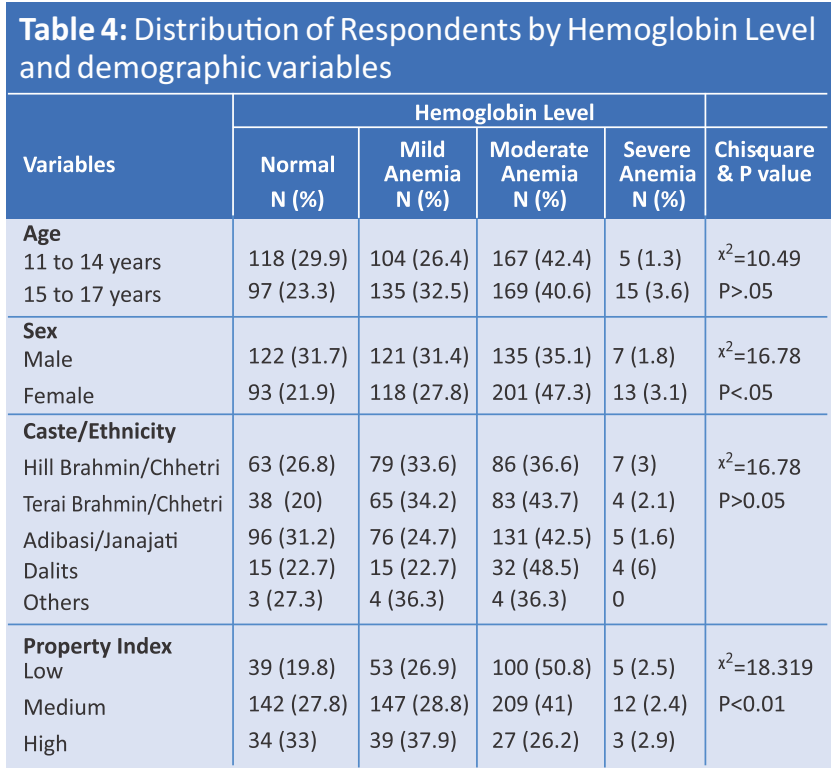

Table 5: Distribution of participants by Hemoglobin level and parents education and occupation.

\begin{tabular}{|c|c|c|c|c|c|}
\hline \multirow[b]{2}{*}{ Variables } & \multicolumn{4}{|c|}{ Hemoglobin } & \multirow[b]{2}{*}{$\begin{array}{l}\text { Chi-square } \\
\text { and P-value }\end{array}$} \\
\hline & Normal & $\begin{array}{l}\text { Mild } \\
\text { Anemia }\end{array}$ & $\begin{array}{l}\text { Moderate } \\
\text { Anemia }\end{array}$ & \begin{tabular}{c|} 
Severe \\
Anemia
\end{tabular} & \\
\hline Father's education & & & & & \multirow{6}{*}{$\begin{array}{l}x^{2}=20.426 \\
P=0.015\end{array}$} \\
\hline Not stated & $5(25)$ & $8(40)$ & $6(30)$ & $1(5)$ & \\
\hline No education & $21(21)$ & $30(30)$ & $47(47)$ & $2(2)$ & \\
\hline Primary education & $36(22.1)$ & $41(25.2)$ & $83(50.9)$ & $3(1.8)$ & \\
\hline Secondary education & $93(25.2)$ & $117(31.7)$ & $148(40.1)$ & $11(3)$ & \\
\hline Higher education & $60(38)$ & $43(27.2)$ & $52(32.9)$ & $3(1.9)$ & \\
\hline Mother's education & & & & & \multirow{6}{*}{$\begin{array}{l}x=29.873 \\
P=<.001\end{array}$} \\
\hline Not stated & $4(22.22)$ & $8(44.44)$ & $6(33.33)$ & & \\
\hline No education & $46(19.6)$ & $67(28.5)$ & $116(49.4)$ & $6(2.6)$ & \\
\hline Primary education & $50(26.6)$ & $51(27.1)$ & $81(43.1)$ & $6(3.2)$ & \\
\hline Secondary education & $76(27.1)$ & $82(29.3)$ & $115(41.1)$ & $7(2.5)$ & \\
\hline Higher education & $39(43.8)$ & $31(34.8)$ & $18(20.2)$ & $1(1.1)$ & \\
\hline Father's Occupation & & & & & \multirow{8}{*}{$\begin{array}{l}x^{2}=32.085 \\
P=0.021\end{array}$} \\
\hline Not stated & $2(20)$ & $1(10)$ & $6(60)$ & $1(10)$ & \\
\hline Agriculture & $86(26.3)$ & $99(30.3)$ & $138(42.2)$ & $4(1.2)$ & \\
\hline Business & $48(22.6)$ & $63(29.7)$ & $91(42.9)$ & $10(4.7)$ & \\
\hline Service & $41(37.6)$ & $37(33.9)$ & $30(27.5)$ & $1(0.9)$ & \\
\hline Labour/Worker & $17(23.6)$ & $19(26.4)$ & $34(47.2)$ & $2(2.8)$ & \\
\hline Foreign employment & $20(27)$ & $19(25.7)$ & $34(45.9)$ & $1(1.4)$ & \\
\hline Others & $1(16.7)$ & $1(16.7)$ & $3(50)$ & $1(16.7)$ & \\
\hline Mother's Occupation & & & & & \multirow{8}{*}{$\begin{array}{l}x^{2}=17.529 \\
P=0.487\end{array}$} \\
\hline Not stated & $2(25)$ & $2(25)$ & $4(50)$ & & \\
\hline Agriculture & $111(26.9)$ & $116(28.1)$ & $177(42.9)$ & $9(2.2)$ & \\
\hline Business & $37(24.2)$ & $42(27.5)$ & $69(45.1)$ & $5(3.3)$ & \\
\hline Service & $20(40.8)$ & $15(30.6)$ & $13(26.5)$ & $1(2)$ & \\
\hline Labour/Worker & $5(20.8)$ & $5(20.8)$ & $13(54.2)$ & $1(4.2)$ & \\
\hline Foreign employment & $14(20)$ & $25(35.7)$ & $28(40)$ & $3(4.3)$ & \\
\hline Housewife & $26(28)$ & $34(36.6)$ & $32(34.4)$ & $1(1.1)$ & \\
\hline
\end{tabular}


Table 6 displays the status of Hemoglobin level of adolescents by number of siblings, type of family and ecological belt. Adolescents who did not have siblings had better hemoglobin (34.8\% normal) level as compared to those having siblings i.e. 1 to 3 (25.9\%), 4 and more (26.4\%) respectively. However, the difference was not significant. Type of family also had no significant effect on hemoglobin level. Adolescents who were from Hill ecological belt had better hemoglobin level (33\% normal) followed by Mountain (30.6\% normal) but the adolescents of Terai had poor hemoglobin level (17.8\% normal), $(p=.001)$.

Table 6: Distribution of hemoglobin level by selected
socio-demographic variables
\begin{tabular}{|l|l|l|l|l|l|}
\hline \multirow{3}{*}{ Variables } & \multicolumn{5}{|c|}{ Hemoglobin } \\
\cline { 2 - 6 } & Normal & $\begin{array}{l}\text { Mild } \\
\text { Anemia }\end{array}$ & $\begin{array}{l}\text { Moderate } \\
\text { Anemia }\end{array}$ & $\begin{array}{l}\text { Severe } \\
\text { Anemia }\end{array}$ & $\begin{array}{l}\text { Chi-Square } \\
\& \text { P Value }\end{array}$ \\
\hline No of sibling & & & & & \\
\hline None & $16(34.8)$ & $8(17.4)$ & $21(45.7)$ & $1(2.2)$ & $x^{2}=5.855$ \\
\hline $1-3$ & $152(25.9)$ & $179(30.5)$ & $239(40.7)$ & $17(2.9)$ & $P=0.44$ \\
\hline 4 \& above & $47(26.6)$ & $52(29.4)$ & $76(42.9)$ & $2(1.1)$ & \\
\hline Type of family & & & & & \\
\hline Nuclear & $129(26.4) \%$ & $142(29.1)$ & $202(41.4)$ & $15(3.1)$ & $x^{2}=1.895$ \\
\hline Joint & $86(26.7)$ & $97(30.1)$ & $134(41.6)$ & $5(1.6)$ & $P=0.595$ \\
\hline Ecological belt & & & & & \\
\hline Terai & $57(17.8)$ & $111(34.7)$ & $140(43.8)$ & $12(3.8)$ & $x^{2}=25.963$ \\
\hline Hill & $109(33)$ & $80(24.2)$ & $135(40.9)$ & $6(1.8)$ & $P=.001$ \\
\hline Mountain & $49(30.6)$ & $48(30)$ & $61(38.1)$ & $2(1.2)$ & \\
\hline
\end{tabular}

\section{DISCUSSION}

The study aimed to assess the nutritional status of school going adolescents through anthropometric measurements and hemoglobin level. The result revealed mean BMI of the study participants was calculated 18.87 with SD 2.79. Significantly higher proportions (47.3\%) of adolescents were underweight and only $45.4 \%$ had normal BMI. Nutritional status of adolescent were low among both urban and rural areas, but severe thinness were higher among of rural (39.3\%) compared to urban (37.5\%) adolescents. Among various socio-demographic variables the age, sex, ethnicity, ecological belt, and meat/fish/egg consumption were found significantly associated in bivariate analysis of BMI in the present study. The adolescents with highest property index (forth quartile) and who consumes fruits, meat/fish/egg and dairy products more frequently had better BMI. The findings of Kedir Teji et al, also supports the present finding; he found the factors independently associated with stunting were place of residence, father's occupation, source of drinking water and age of the adolescents. ${ }^{14}$ This findings also similar with present study. Another study done by Kurz KM (1996) analyzed multiple studies in nutritional studies of 10 to 18 years adolescents and concluded the slow growth was common in 9 studies (27-65\%). Low body mass index (BMI) was high (23-53\%) in 3 studies. It was surprising that boys had a BMI 2 times lower than that of girls relative to sexspecific data. ${ }^{15}$ In present study too the BMI of males was less than the females showing more thinness among male adolescents. A study finding of WHO (2006), conducted in ten South-East Asian countries revealed the similar pattern. The prevalence of protein energy malnutrition (PEM) is high in most countries of the Region. All countries had a very large number of undernourished (underweight and stunted) preschool children. ${ }^{16}$ The finding of National Nutrition Survey 2013 in Afganistan on nutrition status of adolescent girls (10-19 years) keeps contradictions in the status of obesity however supports the status of underweight. They reported that $8.0 \%$ of the adolescent girls were thin and $1.5 \%$ was severely thin. Furthermore $11.6 \%$ of adolescent girls were overweight and only $2.7 \%$ were obese. Among women of reproductive age (15-49 years); at national level $9.2 \%$ of women were thin or undernourished (BMI $<18.5$ $\left.\mathrm{kg} / \mathrm{m}^{2}\right)^{17}$ This finding also match with present finding in many aspects.

The mean Hemoglobin of the adolescents was found 11.13 with SD 1.57 in present study. About three-forth (73.5\%) adolescents found anemic and only $26.5 \%$ adolescents had normal Hemoglobin level. Among anemic, about 30\% were mild, $41 \%$ were moderately anemic and $2.5 \%$ were severely anemic. A cross-sectional community based study on school going adolescents in 2009 carried out by Baral KP and Onta SR revealed the similar results. They found the overall prevalence of anemia among adolescents was very high (65.6\%). Another study conducted by Kanodia P (2016) also found the overall prevalence of anemia was $51.3 \%$ among adolescents. ${ }^{18}$ Singh P et al (2013) conducted a hospital-based study in Far Western Nepal and found that the overall prevalence of anemia was $52 \%$ for both males and females. He also found the mean and SD of hemoglobin was $9.85 \pm 1.87 \mathrm{gm} / \mathrm{dl}$ among anemic population and it was $12.32 \pm 2.41 \mathrm{gm} / \mathrm{dl}$ among total population. ${ }^{11}$ These findings are a bit contradictory with present findings, however the trend was similar. More anemic adolescents were observed in present study and it could be due to more exposure to junk food these days. Kurz KM analyzed multiple studies and finding was that anemia was the most important nutritional problem. Anemia prevalence was high in four studies (55\% in India, 42\% in Nepal, 32\% in Cameroon, 48\% in Guatemala). ${ }^{5}$ The finding of above multiple studies also keep similarity with the present finding.

Higher percentage of adolescents (31.5\%) were found in this study with normal hemoglobin who consumed dairy products daily. Higher percentages of adolescents (43.2\%) were also found having normal hemoglobin level who consumed pulses daily and meat/fish mostly (28.9\%) but the association was not found significant. However, factors like fathers education did not have a significant impact on occurrence of Anemia.

Sex, property index of the family, the ecological belts and mothers' education were positively associated with hemoglobin. The females had significantly poor hemoglobin as compared to males. A cross-sectional community based study on school going adolescents in 2009 carried out by Baral KP and Onta SR revealed the similar results. Among female adolescents, the figure for anemia was high (78.3\%) than males (52.3\%). Difference between rural and urban anemia found striking. Accounting $83.7 \%$ and $71.9 \%$ of female adolescents were found anemic in urban and rural areas respectively. The prevalence of anemia among early 
adolescent males was found higher (age group of 10-14 years) with $64.3 \%$ in rural and $71.4 \%$ in urban area. In the same age group, $85.7 \%$ of the female adolescents in the urban and $77.8 \%$ of the same in the rural areas were found anemic. ${ }^{7}$ Kanodia P (2016) conducted a study and found that the overall prevalence of Anemia was observed 51.3\%. The prevalence was significantly more in pre-menarche age and undernourished girls $(p<0.05)$. However, factors like diet (vegetarian/non-vegetarian), worm infestation and parental education did not have a significant impact on occurrence of Anemia. ${ }^{18}$ This finding keeps some contradiction with present finding. Singh $\mathrm{P}$ et al, conducted a hospital-based study and found compatible results with present finding; the overall prevalence of anemia was $52 \%$ for both males and females. ${ }^{11}$ Dubey RK et al conducted a hospital based retrospective study to determine the prevalence of anemia in adolescent females and found that out of 1888 subjects 793 adolescents (42\%) were diagnosed as anemic; $59.14 \%$ being mildly anemic and $32.02 \%$ moderately anemic while $8.82 \%$ suffered from severe Anemia. ${ }^{19}$ Another finding by Jha Vijay Kumar and Gupta P also supports the present finding. He found that the overall prevalence of anemia was found to be $68.8 \% .^{20}$

\section{CONCLUSION}

The prevalence of overall iron deficiency anemia among school-going adolescents was $73.5 \%$. About $30 \%$ were suffering from mild, $41 \%$ from moderate, and $2.5 \%$ from severe anemia. The prevalence of overall underweight and overweight was 54.6\%. Among them, $47.3 \%$ had low BMI, and $7.3 \%$ had overweight/obese. Only $45.4 \%$ had normal hemoglobin level. Age, sex, ethnicity, mother's occupation, ecological belt, and father's education found significantly associated with BMI status of adolescents.

Similarly, age, sex, ecological belt, and mother's education found significant with hemoglobin level. Males had better hemoglobin level than females. Adolescents with higher level of mother's education had better hemoglobin level.

\section{REFERENCES}

1. Ohlhorst D., Sarah. Russell, Robert et al., Nutrition Research to Affect Food and a healthy Lifespan. AdvNutr, vol. 4:579-584, Sep 2013.

2. Akhtar N. and Sondhya FY., Nutritional status of adolescents in Bangladesh: Comparison of severe thinness status of a low-income family's adolescents between urban and rural Bangladesh. J Educ Health Promot. 2013; 2: 27.

3. Assefa, Selomon. Mossie, Andualem. Hamja, Leja. Prevalence and Severity of Anemia among School Children in Jimma Town, South West Ethiopia. BMC Hematology Vol. 14:3.2014. doi: 10.1186/ 2052-1839-14-3. (4)

4. Scatter good, Gary. Nepal Study: A Review of the Situation in Selected South-East Asian Countries. Nepal. 2016.

\section{RECOMMENDATIONS}

- Policy needs to formulate to encourage healthy food habit and discourage regular consumption of junk foods to the children and adolescents.

- Different training and workshops should lunch to make the parents aware regarding the value of nutrition.

- School based nutritional interventions recommended to provide the most effective and efficient way to reach school-going adolescents' nutrition.

- Large scale research is essential to dig out the real problem of adolescents, especially the girl adolescents in Nepal as well as other developing countries so that Governments and other agencies can develop policies and programs for nutrition.

\section{LIMITATION OF THE STUDY}

- This study based on the sample survey of only 810 adolescents of 10-17 years, attending schools; the conclusion of this study may not represent the outschool adolescents.

- Nutritional status was examined through height, weight, and hemoglobin; other forms of nutrition was not covered.

- This study was confined only within selected districts of Eastern Development Region of Nepal and so may not represent the characteristics of the whole country.

\section{ACKNOWLEDGEMENT}

We are thankful to MIHRD Team members for their valuable suggestions. We never forget the uncompromising help of Mr Meghraj Dahal for his support during data collection and the participants of this study for their cooperation in all situations.

\section{CONFLICT OF INTEREST}

None

\section{FINANCIAL DISCLOSURE}

Selffunded
5. Onabanjo, Oluseye Olusegun. Balogun, OladimejiLookman Anthropometric and Iron Status of Adolescents from Selected Secondary Schools in Ogun State, Nigeria. Childhood Obesity and Nutrition, Vol 6, Issue 2, 2014.

6. Srivastava, Anurag. Mahamood E, Syed. Srivatava M, Payal et al. Nutritional Status of School-Age Children: A Scenario of Urban Slum in India. Arch Public Health. 2012; 70(1): 8. doi: 10.1186/0778-7367-70-8

7. Baral, KP. and Onta, SR. Prevalence of Anemia Amongst Adolescents in Nepal: a community based survey. Morang District. Nepal. Nepal Med Coll J. Vol. 11(3)2009:179-82. (1)

8. Balc YI., Karabulut A., Gürses D., ÇövütiE., Prevalence and Risk Factors of Anemia among Adolescents in Denizli, Turkey. Iran J Pediatr; Vol 22 (No 1) 2012, Pp: 77-81 
9. Prendergast, AJ and Humphrey JH. The Stunting Syndrome in Developing Countries. PaediatrInt Child Health. 2014 Apr : 34 (4);250-265.

10. Amatya, M., Khanal, B. and Yadav, S. R. Body Mass Index of Nepalese Medical Students: A Cross-sectional Study. International Journal of Development Research Vol. 4, Issue, 3, 2014. pp. 746-748.

11. Singh P., Khan S., Ansari M., Mitta RK., Anemia amongst Adolescent Girls and Boys Attending Outpatients and Inpatient Facilities in Far Western Part of Nepal. Ibnosina Journal of Medicine and Biomedical Sciences. Vol 5, No 6 (2013).

12. Devkota, Suresh Chandra. De, Asis. Sathian, Brijesh. Nutritional Deficiencies: Major Public Health Problem in Nepal.American Journal of Public Health Research. Vol. 3, No. 4A, 2015, pp 1-5. doi: 10.12691/ ajphr-3-4A-1

13. Miah, Md. Shamim. Rahman, M. Nannur. Prodhan, UK. Linkon, MR. et al. Prevalence of Iron Deficiency Anemia Among Adolescent Girls and its Risk Factors in Tangail region of Bangladesh. IJRET: International Journal of Research in Engineering and Technology. Volume: 03 Issue: 06| Jun-2014. Available @ http://www.ijret.org

14. Teji, Kedir., Dessie, Yadeta., Abdo, Meyrema., 2013; Anaemia and nutritional status of adolescent girls in Babile District, Eastern Ethiopia. The Pan African Medical Journal. 2016;24:62.
15. Kurz, KM. Adolescent nutritional status in developing countries. PROCEEDINGS OF THE NUTRITION SOCIETY. 1996 Mar; 55(1B):321-31.

16. WHO. Adolescent Nutrition: A Review of the Situation in Selected South-East Asian Countries, 2006. [Internet] Assessed on 14 March 2017, Available at:http://www.searo.who.int/ entity/child_ adolescent/documents/sea_nut_163/en/

17. UNICEF. National Nutritional Survey, Afganistan Survey Report, UNICEF Country Office, Afganistan, 2013. [Internet] Available at: http://reliefweb.int/sites/reliefweb.int/files/resources/Report\%20 NNS\% 20 Afghanistan \%20 2013\% 20 (July\%2026-14).pdf [Accessed, 15 March 2017]

18. Kanodia, P., Bhatta M., Rajbhandari Singh R., Bhatta NK., el al. a study of anemia among adolescent girls in eastern part of Nepal. Journal of College of Medical Sciences-Nepal, Vol-12, No 1, Jan-Mar 016.

19. Dubey RK., Padmavathi P., Jayan A., Gautam N., Neupane Y., and Sinha AK., Prevalence of Anemia Amongst Adolescent Females in South Western Nepal. The Pharma Innovation - Journal Vol. 2 No.7, 2013;.pp84-89

20. Shah BK. and Gupta P., Anemia in Adolescent Girls: A Preliminary Report from Semi-urban Nepal. Indian Pediatrics. Vol 39, 2002:1126-1130. 